\title{
SPRU
}

Working Paper Series SWPS 2015-25 (September)

\section{From Market Fixing to Market-Creating: A New Framework for Economic Policy}

Mariana Mazzucato

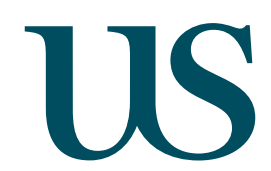

University of Sussex 


\section{SPRU Working Paper Series (ISSN 2057-6668)}

The SPRU Working Paper Series aims to accelerate the public availability of the research undertaken by SPRU-associated people of all categories, and exceptionally, other research that is of considerable interest within SPRU. It presents research results that in whole or part are suitable for submission to a refereed journal, to a sponsor, to a major conference or to the editor of a book. Our intention is to provide access to early copies of SPRU research.

\section{Editors}

Tommaso Ciarli

Daniele Rotolo

Associate Editors

Florian Kern

Paul Nightingale,

Ben Martin, \&

Ohid Yaqub

Matias Ramirez

Joe Tidd \&

Carlos Sato

Maria Savona \&

Mariana Mazzucato

Andrew Stirling Transitions

Caitriona McLeish

\section{Area}

Energy

Science, \& Technology Policy

Development

Technology Innovation

Management

Economics of Technological Change

Civil military interface
Contact

T.Ciarli@sussex.ac.uk

D.Rotolo@sussex.ac.uk

P.Nightingale@sussex.ac.uk

B.Martin@sussex.ac.uk

O.Yaqub@sussex.ac.uk

Matias.Ramirez@sussex.ac.uk

J.Tidd@sussex.ac.uk

C.E.Y.Sato@sussex.ac.uk

M.Savona@sussex.ac.uk

M.Mazzucato@sussex.ac.uk

A.C.Stirling@sussex.ac.uk

C.A.McLeish@sussex.ac.uk

\section{Disclaimer}

The works available here are the responsibility of the individual author(s) and do not necessarily represent the views of other SPRU researchers. As matters of policy and practice, SPRU does not endorse individual research contributions.

\section{Guidelines for authors}

Papers shall be submitted in pdf or Word format. They should contain a title, an abstract, and keywords. Papers should be submitted to one of the Editors, who will process them and send them to the appropriate Associate Editor. Two members of SPRU will be asked to provide a short written review within three weeks. The revised versions of the paper, together with a reply to the reviewers, should be sent to the Associate Editor, who will propose to the Editors its publication on the series. When submitting the authors should indicate if the paper has already undergone peer-reviewing, in which case the Associate Editors may decide to skip internal review process.

\section{Websites}

SWPS: www.sussex.ac.uk/spru/research/swps

IDEAS: ideas.repec.org/s/sru/ssewps.html

Research Gate: www.researchgate.net/journal/2057-6668_SPRU_Working_Paper_Series 


\title{
From Market Fixing to Market-Creating: A new framework for economic policy
}

\author{
Mariana Mazzucato \\ RM Phillips Professor in the Economics of Innovation \\ Science Policy Research Unit, University of Sussex, UK \\ www.marianamazzucato.com
}

\begin{abstract}
Many countries are pursuing innovation-led 'smart' growth, which requires certain types of long-run strategic investments. This paper argues that such investments require public policies that aim to create markets, rather than just 'fixing' market failures (or system failures). Such 'mission-oriented' investments have led to men walking on the moon (which created spillovers across the economy) and are today catalyzing investments to tackle climate change around the world. In the two abovementioned cases, public agencies not only 'de-risked' the private sector, but also led the way in terms of shaping and creating new technological opportunities and market landscapes. Only then was the private sector willing to invest. This paper considers four key questions that arise from a 'market creating' framework: (1) decision-making on the direction of change; (2) the nature of (public and private) organizations that can welcome the underlying uncertainty and discovery process; (3) the evaluation of mission-oriented and market-creation policies; and (4) the ways in which both risks and rewards can be shared so that 'smart' innovation-led growth can also result in 'inclusive' growth.
\end{abstract}

Keywords: innovation policy, mission-oriented, market failures, system failures, directionality, smart growth, inclusive growth.

JEL Code: H1, L1, L2, O1, 03

Note: An earlier version of this paper was commissioned by Innovate UK (TSB) "A Mission Oriented Approach to Building the Entrepreneurial State", UK Technology Strategy Board November 2014T14/165. Support was also received by the Ford Foundation and by the European Commission's Horizon 2020 programme (Dolfins project). Comments from Caetano Penna, and an anonymous referee from the SPRU working paper series are greatly appreciated. All errors remain my own. 


\section{Societal Challenges and opportunity driven investments}

Innovation agencies in various countries and in transnational organizations like the OECD and the European Commission are increasingly considering socio-economic-technological 'challenges' that innovation policies can tackle (EC Innovation Union; OECD Innovation Strategy). ${ }^{1}$ In such challenges, which can relate to climate change, cancer, or the demographic-ageing crisis, the idea is that innovation policy should produce solutions for societal problems. This paper argues that such challenge-driven innovation policies require the traditional market failure justification for policy intervention to be complemented with a more active market creating justification. To this end, the paper draws on and advances an analysis of the role of public policy in the economy that can provide a more strategic and mission-oriented approach.

Societal challenges, such as climate change, youth unemployment, obesity, ageing, and rising inequality, have helped form a new agenda for innovation and growth policy that requires politicians and policy makers to 'think big' about what kind of technologies and socio-economic policies can fulfill visionary ambitions to make growth more 'smart', 'inclusive' and 'sustainable'. Although solving such challenges is not strictly a technological matter (it also requires behavioral and systemic changes), it also has much to learn from those mission-oriented feats that led to putting a man on the moon and to the emergence of new general-purpose technologies ranging from the Internet to biotechnology and nanotechnology (Foray et al., 2012). Achieving those missions required the public and private sectors to work together to create new technologies and sectors (Mowery et al. 2010; Ruttan, 2006). Crucially, the public side of such partnerships was not limited to facilitating and de-risking the private sector; it actively envisioned the direction of changedefining missions as part of this risk-taking (Mazzucato, 2013a). Such directionality did not necessarily occur top-down, through centralized ministries, but was often set through decentralized activity of group of public agencies and departments that selected particular sectors, technologies and broadly defined areas to develop. Appropriately, Block and Keller (2011) referred to this decentralized directionality as a "developmental network state". Given the immense risks involved in choosing to develop particular sectors (such as nanotechnology), technologies (GPS, for example) and broadly defined areas (such as the green revolution), the relevant public institutions had to welcome the underlying uncertainty that such choosing entails; some options win (such as the Internet) while others fail (for example, the Concorde plane). Indeed, the success of organizations like DARPA, in the US Department of Defense, has been attributed to the attention paid to experimental processes to enable organizational learning. Albert Hirschman emphasized the need to use 'policy as process' as the motto through which such learning could be fostered in the public sector (Hirschman, 1967; Rodrik, 2014). And today's fracking revolution in the US production of shale gas, has been promoted by decades of explorative innovaiton by the Department of Energy (Shellenberger et al. 2010).

If policy makers intend for societal challenges that combine social, political, economic and technological ambitions to become the new 'missions', challenges will need to translate into specific problems to solve (so that it is clear when they are achieved) while remaining broad enough to catalyze investments across many sectors. In order for challenges to become concrete missions, they must be problem-specific, but not overly narrow. Yet, the key problem that such mission setting currently faces is the fact we are living through an era in which the public sector is being told to step back and focus only on 'leveling the playing field', without daring to pick directions. This represents a crisis of imagination with regard to the role of the state in the economy, which Judt (2011) referred to also as a 'discursive' crisis. Limiting our understanding of the role of the public sector to one that simply 'administers', 'fixes', 'regulates', 'meddles in', and at best 'facilitates' and 'de-risks' the private sector, prevents us from thinking creatively about how to allow public sector vision, risk-taking and investment to lead and structure the necessary transformational changes. This same lack of faith in public institutions, driven mainly by the 1980s Public Choice Theory revolution, means we are not investing internally within the public sector's own organizations and institutions to create the new capabilities and competencies that are

\footnotetext{
${ }^{1}$ See Innovation Union Flagship Initiative in the Europe 2020 strategy http://ec.europa.eu/research/innovationunion/index_en.cfm.
} 
essential for any innovative agent. And the rapid rise of outsourcing contributes to this fall in public capacity building (Crouch, 2004).

Unfortunately, the biased view of the public sector has been symptomatic of those alternative approaches, such as the 'systems of innovation' approach (Lundvall, 1992). This is because even in such an approach, by viewing the public sector as only the solution to a problem that arises from coordination failures or the need to create linkages between institutions, the sector's role has inevitably been a passive one, facilitating change, rather than leading it, and has given little guidance for the 'directionality' required in a world with different pathways (Stirling, 2014). The present paper seeks to provide a new framework through which such vision and ambition can be formulated, guided, organized, evaluated and managed.

A key to the problem is the fact that the prevailing policy framework in economics justifies state intervention only if it is geared towards fixing situations in which markets fail to 'efficiently' allocate resources. This market failure approach suggests that governments intervene to 'fix' markets by investing in areas with 'public goods' characteristics (such as basic research, or drugs with minimal market potential) and by devising market mechanisms to internalize external costs (such as pollution) or external benefits (such as herd immunity). According to this approach, the state should only aim to fix a market failure if such an action does not lead to an even worse outcome due to "government failure" (Tullock et al., 2002). For instance, the state should intervene in a way that does not displace (crowd out) private enterprise, which is considered to be superior in terms of selecting and managing investments (Friedman, 1979; Aschauer, 1989). In other words, the state should not 'direct' the economy or try to pick winners; instead, it should step back and concentrate on facilitating private initiative and optimizing market performance to maximize the rate of progress.

The market failure framework is problematic for addressing societal challenges because it cannot explain and justify the kinds of transformative mission-oriented investments that in the past picked directions, coordinated public and private initiatives, built new networks, and drove the entire techno-economic process, which resulted in the creation of new markets, not just in the fixing of existing ones. The market failure approach is more useful for describing a steady state situation in which public policy aims to put patches on existing development trajectories provided by markets, but not to dynamically create and shape new trajectories.

The key problem is that any framework that focuses on fixing failures, especially market failures, does not embody any explicit justification for the kind of mission-oriented directionality (and 'routes' within directions), which was required for innovations such as the Internet and nanotechnology and is required today to address societal challenges ranging from climate change to ageing. Secondly, by not considering the state as a lead investor and market creator, market failure theory (MFT) has failed to produce the insights into the type and structure of public sector organizations that are needed in order to provide the depth and breadth of high-risk investments. Thirdly, because it lacks a clear framework that posits the objective of state policy to create and shape markets, MFT cannot evaluate and assess such mission-oriented investments when they happen. Fourthly, by not describing the state as a lead risk-taker and investor in this process, MFT has avoided a key question regarding the distribution of risks and rewards between the state and the private sector.

The paper addresses these four challenges by asking the following questions:

(1) How can public policy be understood in terms of setting the direction and route of change; that is, shaping and creating markets rather than just fixing them (DIRECTIONALITY)?

(2) How can this alternative conceptualization be translated into new indicators and evaluation tools for public policies, beyond the micro-economic cost/benefit analysis and macro-economic appraisal of crowding in/crowding out that stem directly from the market failure perspective (EVALUATION)?

(3) How should public organizations be structured so they accommodate the risk taking, explorative capacity and capabilities needed to envision and manage contemporary challenges (ORGANIZATIONS)? 
(4) How can public investments along the innovation chain result not only in the socialization of risks, but also of rewards, enabling smart growth to also be inclusive growth (RISKS and REWARDS)?

While the questions may seem broad, it is their connection that lies at the center of a market creation framework. Policy that aims to actively create and shape markets requires indicators that assess their performance along that particular 'transformational' objective. The state's ability and willingness to take risks, embodied in transformational changes, requires an organizational culture (and policy capacity) that welcomes the possibility of failure and experimentation and is rewarded for 'successes' so that 'failures' can be covered and the next round repeated.

This alternative view (policy framework) of policy making builds on the inspirational work of Karl Polanyi (2001 [1944]), an economic historian and sociologist who understood markets as being deeply embedded in social institutions, with policy not standing on the side-lines, but within the very market creation process. In his epic book The Great Transformation, Polanyi described the way in which capitalist markets are deeply 'embedded' in social and political institutions, rendering meaningless the usual static state vs. market juxtaposition: "[t]he road to the free market was opened and kept open by an enormous increase in continuous, centrally organized and controlled interventionism" (2001 [1944], p. 144). Polanyi's description also builds on John Maynard Keynes' challenge for governments to think big: "The important thing for Government is not to do things which individuals are doing already, and to do them a little better or a little worse; but to do those things which at present are not done at all" (Keynes, 1926, p. 46). This view of policy has implications for the transformational effect of government policies, which is not found in macroeconomic interpretations of Keynes' work.

Before considering an alternative analysis, it is crucial to understand the market failure framework on its own grounds.

\section{MARKET FAILURE THEORY}

Market failure theory justifies public intervention in the economy only if it is geared towards fixing situations in which markets fail to efficiently allocate resources (Arrow, 1951). The market failure approach suggests that governments intervene to 'fix' markets by investing in areas with 'public goods' characteristics (such as basic research, or drugs with little market potential) and by devising market mechanisms to internalize external costs (such as pollution) or external benefits (such as herd immunity). Figure 1 depicts five key sources of market failures; that is, factors or behaviors that result in costs or benefits that are not reflected in the price system.

Within the mainstream framework, market failure is a necessary but not sufficient condition for governmental intervention (Wolf, 1988). The sufficiency results from an assessment that the gains from the intervention outweigh the associated costs due to "governmental failures" (Tullock et al., 2002), such as capture by private interests (nepotism, cronyism, corruption, rent-seeking) (Krueger, 1974), misallocation of resources (for example, picking losers) (Falck et al., 2011), or undue competition with private initiatives (crowding out) (Friedman, 1979). Consequently, there is a trade-off between two inefficient outcomes; one is generated by free markets (market failure) and the other by governmental intervention (government failure). The solutions advocated by NeoKeynesians focus on correcting failures such as imperfect information (Stiglitz and Weiss, 1981). Solutions advocated by public choice scholars (Buchanan, 2003) focus on leaving resource allocation to markets (which may be able to correct their failures on their own).

While MFT provides interesting insights, it is at best useful for describing a steady state scenario in which public policy aims to put patches on existing trajectories provided by markets. It is less useful when policy is needed to dynamically create and shape new markets; that is, 'transformation'. This means it is problematic for addressing innovation and societal challenges because it cannot explain the kinds of transformative, catalytic, mission-oriented public investments that created new technologies and sectors that did not exist before (the Internet, nanotech, biotech, clean-tech), and which the private sector feared. Such mission-oriented investments coordinated public and private initiatives, built new networks, and drove the entire techno-economic process, which resulted in the creation of new markets. 
Figure 1: Types and sources of market failures

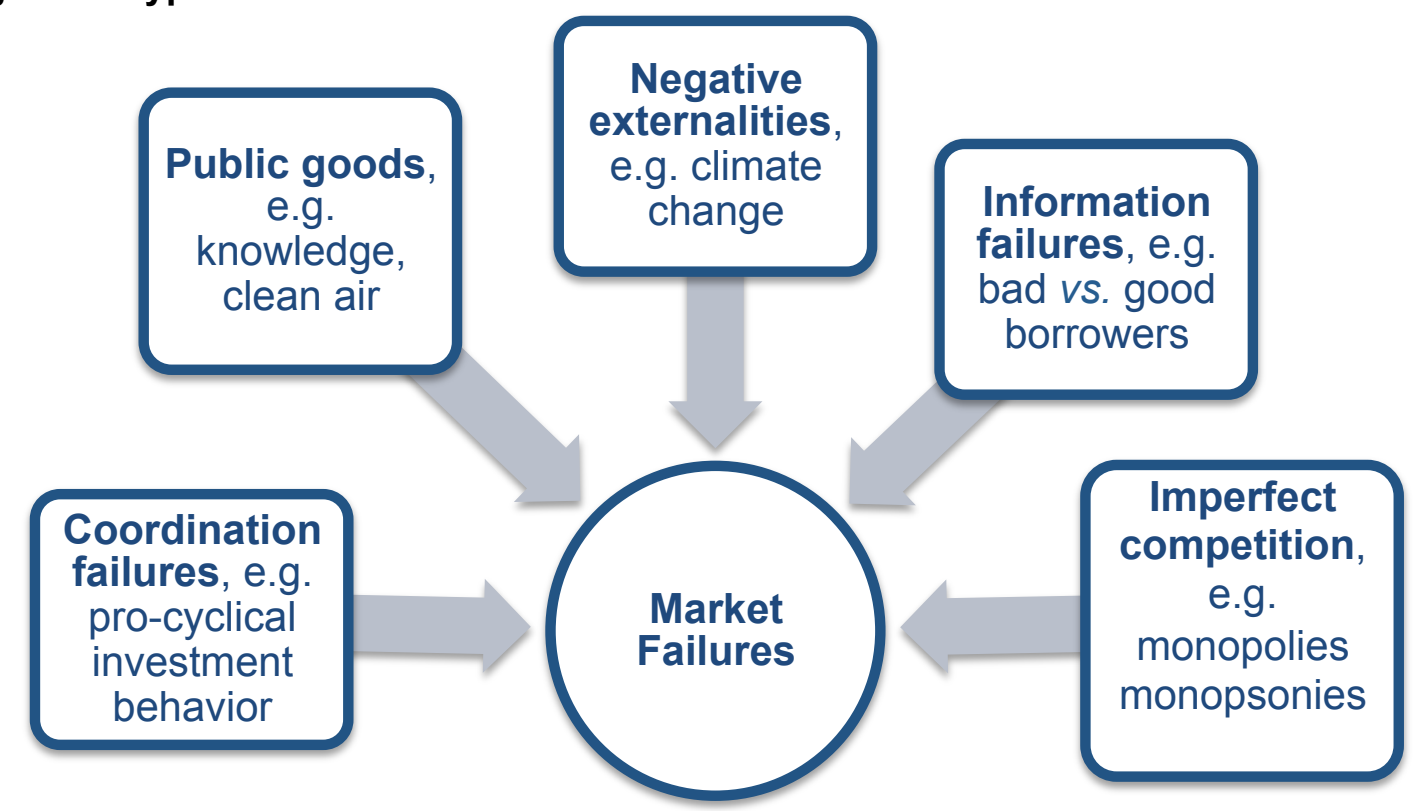

Source: Based on typology of market failures developed by Mazzucato and Penna (2014).

MFT has four key limitations, which continue to guide policy making today. These are the ability of the state to set the direction of change, to form indicators through which to evaluate its transformational impact, to set up organizations in the public sector that are willing and able to welcome rather than fear failure, and the ability to earn some return from the upside to fund the many inevitable failures that are part and parcel of the innovation process. These limitations are discussed below.

MF1. Coordination failures. These occur when agents fail to coordinate their expectations and preferences throughout the business cycle, leading to markets failing to reach an equilibrium (supply does not match demand, workers do not find employment, savings do not get invested). Business cycles create an inter-temporal dynamic, which make it difficult to coordinate expectations and preferences, giving rise to situations in which the economy follows a Paretoinefficient path (Stiglitz, 1974). In such situations, capital, labor and natural resources will be underutilized, because the supply and demand for them do not match (Bator, 1958; Stiglitz, 1991). From this perspective, government intervention would be justified as a way to address the coordination failure that arises from private agents (such as banks and firms) being too pro-cyclical (lending and investing too much in the boom and too little in the bust), putting the economy on a downwards path. Therefore, market failure theory assumes that the state is risk-neutral and capable of absorbing risk during an economic crisis, spreading risk over time and cross-sectionally (Arrow and Lind, 1970). It is this assumption that justifies the promotion of countercyclical fiscal and monetary policies. For instance, in times of crisis, greater risk aversion of private agents may lead to underinvestment. To address this issue, the state may increase public investment to provide short-term fiscal stimulus to keep the economy running, or it may decrease interest rates in order to indirectly de-risk private investments. In this view, directionality is provided by markets. An implicit corollary of this coordination failure intervention is that if the public sector invests too much during a boom, it risks crowding out private finance, particularly if investments are debt-financed (Friedman, 1979), but not only in such cases (for example, crowding out can also occur if public investment leads to changes in exchange rates). In such situations, fiscal consolidation (austerity measures, contractionary fiscal policy) may result in the expansion of private investments (Giavazzi and Pagano, 1990).

MF2. Public good failures (for example, provision of clean air or new knowledge) and situations of imperfect competition (for example, natural monopolies, network effects, supply and demandside economies of scale). These are both key reasons for industrial policies. Wherever private lenders have limited incentives to finance projects with public good characteristics (non-excludable and non-rival), or in situations of imperfect competition, the market is not an efficient allocator of resources, which justifies state intervention. Examples include private markets underfunding goods 
with very high spillovers (such as basic research that generates new knowledge), or socially desirable infrastructure projects with positive externalities. Both of these types are characterized by value that cannot be internalized by private agents. Research and development (R\&D) investments generate new knowledge that cannot be fully appropriated by the original investor (who cannot 'exclude' other agents from using the knowledge to their own benefit). Thus, private agents tend to underinvest in R\&D and innovation because they cannot internalize benefits that would compensate for the development costs and make the investments worthwhile. Competition failures arise when there are high natural barriers to entry (due to scale economies or network effects), which also lead to Pareto-inefficient situations (Stiglitz, 1991). In order to correct for such types of market failure, the state may invest in early-stage blue sky research, infrastructure and other public works, enforce competition policies, regulate natural monopolies, establish early technical standards, and so on. All of these potential sources of failures focus on using macro industrial policies to promote investments in public goods that are under-produced in prevailing market conditions or tackle situations of monopoly and monopsony (by promoting the entry of new agents to increase the pool of producers and consumers or avoiding collusion, thereby fostering competition). In order to minimize the risk of governmental failure, innovation policies are often designed to be 'neutral', to avoid favoring or disfavoring specific private agents. This view became dominant in the 1990s, when 'diffusion-oriented' policies (focused on 'getting the conditions right') replaced mission-oriented technology policies (Chiang, 1991). In the diffusion-oriented paradigm, policies that promote the supply of public goods are supposed to create the 'right' conditions for innovation. This is done, for example, by de-risking the private sector (through tax incentives) rather than picking winners. The expression 'picking winners' is commonly used to describe policies that are strongly directive and benefit specific firms, technologies and sectors, which many people believe will inevitably lead to government failure (Falck et al., 2011).

MF3. Information failures arising from incomplete markets with high transaction costs and information asymmetries; for example, bad vs. good borrowers (leading to adverse selection or moral hazard behaviors). Such market failures take place at a more microeconomic level, creating inefficiencies associated with non-equilibrium situations that result from the interaction between agents (microeconomic exchanges). For example, microeconomic Pareto inefficiencies may be caused by information asymmetries that lead to adverse selection of potentially good borrowers (Stiglitz and Weiss, 1981). They may also be the result of high costs to carry out a transaction through markets (Coase, 1960). Classic examples are the lack of finance for small enterprises or for R\&D and innovation projects, both of which are risky and uncertain. Underinvestment in R\&D projects due to information asymmetries can even occur in the presence of strong intellectual property laws, macroeconomic stability, free-trade, and contract enforcement, because markets are 'incomplete' (Stiglitz, 1991). In these situations, public investment in SMEs and innovation, through loans, equity or grants, would be justified in order to promote economic diversification, growth and development. To minimize the risk of government failure through capture by private interests or the risk of crowding out, the preferred policies should be neutral and simply de-risk the private sector across the board, without picking favorite firms or sectors.

MF4. Negative externalities arising from the production or use of goods and services such as climate change, traffic congestion, or antibiotic resistance, for which there is no market. In this perspective, most societal challenges are seen as negative externalities. Such failures work at the system level; that is, they amount to 'system failures'. The socio-economic system as a whole results in 'costly' outcomes that are undesirable from a societal point of view. For instance, climate change can be seen as a negative externality from carbon-intensive production methods or the burning of fossil fuels. The Stern Review (Stern, 2006) on the economics of climate change states that: "Climate change presents a unique challenge for economics: it is the greatest example of market failure we have ever seen" (Stern, 2006, p. 1). Negative externalities are not reflected in the price system: there is no 'equilibrium' price because there is no market for negative externalities. Economists often call for market-based mechanisms (such as carbon pricing or carbon taxes) or neutral technology policies (such as tax breaks) to correct for this type of market failure, both of which would minimize the risk of government failure by leaving the direction of change to be determined by market forces.

The key contention of the present paper is that while market failure theory is useful for addressing some of the confined areas listed above, it cannot explain and justify the more ambitious role that 
the state has historically played in shaping and creating markets; that is, transforming them rather than just fixing them. Behind the investments that led to key technological revolutions and generalpurpose technologies was the active hand of the state: the mass production system, aviation and space technologies, nuclear power, information technologies and electronics, and the Internet (Ruttan, 2006). The investments that led to the Internet, for example, were not confined to public goods areas; their breadth covered the entire innovation chain from basic research to applied research and early-stage financing of companies (Block and Keller, 2011). These investments, like those that lay behind nanotechnology and biotechnology, were driven by a vision to create new markets rather than to fix network externalities within existing ones. Thus, a new framework to guide public policies must account for the role of the state in directing investments, creating markets, and taking on risks and uncertainties as lead investor, with private companies only entering later. This expanded role of the state can build on several 'heterodox' economics literatures that have emphasized the state's transformational capacity.

\section{INSIGHTS ON MARKET SHAPING/CREATING FROM ALTERNATIVE THEORIES}

The systems of innovation approach has been crucial for highlighting deficiencies in the market failure perspective, as it regards innovation policy. This is due to the inability of MFT to tackle lockin effects and to specific types of institutional failures that arise from feedback processes along the entire innovation chain (Verspagen, 2006). For this reason, systems of innovation policies focus on the need for nations to build a "network of institutions in the public and private sectors whose activities and interactions initiate, import, modify and diffuse new technologies" (Freeman 1995). The emphasis here is not on the stock of R\&D but on the circulation of knowledge and its diffusion throughout the economy (Lundvall, 1992). Institutional change is not assessed through criteria based on static allocative efficiency, but rather on how such change promotes technological and structural change. The perspective is neither macro nor micro, but more meso, where individual firms are seen as part of broader network of firms with which they cooperate and compete. However, while the systems of innovation approach has been key in identifying dynamic system failures, it has not been explicit in creating an alternative market-creating framework that can guide economic policy. This is the goal of the remainder of this paper. In order to develop a transformational market creation/shaping policy framework, in the spirit of Karl Polanyi's understanding of markets being created by active public policy, I draw on insights from different bodies of thought that have considered the role of the state in the process of fostering innovation-led growth. These are: (a) science and technology policy research (on mission-oriented policies); (b) development economics (on 'developmental states'); (c) evolutionary economics (on shifts in technological trajectories and techno-economic paradigms); and (d) my own work (Mazzucato, 2013a) on the 'entrepreneurial state' regarding the lead risk-taking role of government. In section 4 , I use these insights to consider new questions for economic policy (not only innovation policy) that can help guide a market-creating framework. The fact that these four bodies of thought have not previously been linked, and have not been clearly positioned to critique the key tenets of market failure theory, has prevented them from having the impact they could have had on our understanding of how to guide, evaluate and manage public policy.

\section{a) Science and Technology Policy Research: Mission-Oriented Innovation Policy}

The history of innovation policy, studied especially through the systems of innovation approach (Freeman, 1995), provides key insights into the limits of market failure theory with regard to justifying the depth and breadth of investments that have been necessary for the emergence of radical technological change. Innovation policy has historically taken the shape of measures that (1) support basic research, (2) aim to develop and diffuse general-purpose technologies, (3) develop certain economic sectors that are crucial for innovation, and (4) promote infrastructural development (Freeman and Soete, 1997 [1974]). The justification of innovation policies has changed over time. Military motives predominated in the 1950s and 1960s, while the aim since the 1970 s has been to improve economic and competitive positions. In the 1980s, innovation policy became increasingly justified due to market failure. Innovation policies driven by military motives have been described as mission-oriented because they have aimed to achieve clearly defined 
technical goals. In recent years, there have been calls for a return to such policies to address 'grand societal challenges' (Mowery et al., 2010). However, Foray et al. (2012) contrasted missions of the past, such as putting a man on the moon, with such contemporary missions as tackling climate change. While past missions aimed to develop a particular technology (with the achievement of the technological objective signaling that the mission was accomplished), contemporary missions have addressed broader and more persistent challenges, which require long-term commitments to the development of technological solutions. Indeed, the Maastricht Memorandum (Soete and Arundel, 1993) provided a detailed analysis of the differences between 'old' and 'new' mission-oriented projects, showing that "older projects developed radically new technologies through government procurement projects that were largely isolated from the rest of the economy, though they frequently affected the structure of related industries and could lead to new spin-off technologies that had wide-spread effects on other sectors. In contrast, [contemporary] mission-oriented environmental [and other] projects will need to combine procurement with many other policies in order to have pervasive effects on the entire structure of production and consumption within an economy" (p. 50). While many mission-oriented policies used to be tied to military motives (such as the origin of DARPA in the US Department of Defense), they have more recently been used to set up dynamic public agencies in other mission-oriented areas like energy security (ARPA-E) and health (National Institutes of Health, NIH). Indeed, the $\mathrm{NIH}$ is the second biggest source of innovation funding after the Department of Defense, with spend in 2012 reaching US $\$ 32$ billion. Angell (2005) claimed that such expenditures are the source of most of the radical innovations in the sector; that is, new molecular entities with priority rating (with private pharma focusing more on the incremental drugs and on development).

The mission-oriented literature has developed many useful empirical studies. These include analysis of different technology policy initiatives in the USA (Chiang, 1991; Mowery et al., 2010), in France (Foray, 2003), in the UK (Mowery et al., 2010), and in Germany (Cantner and Pyka, 2001); and studies of mission-oriented agencies and policy programs, including military R\&D programs (Mowery, 2010), the National Institutes of Health (Sampat, 2012); grand missions of agricultural innovation in the USA (Wright, 2012); and energy (Anadón, 2012). However, the literature has not integrated the empirical insights to provide a fully-fledged theory that contrasts its position to that of the four market failure categorizations discussed above. Consequently, the studies have resulted in ad-hoc theoretical understandings and policy advice on how to manage mission-oriented initiatives, without tackling the key justifications for mission-oriented investments in a way that contrasts the justifications which arise from market failure theory. In particular, the framework has been limited to looking at agencies that focus on science, technology and innovation policies. Doing so ignores the relationship between types of finance and innovation development. It also overlooks, for example, the rise of public financial institutions like state investment banks (such as KfW in Germany or the China Development Bank, Sanderson and Forsythe, 2013) as sources of mission-oriented finance, especially as private finance has increasingly retreated from financing the real economy (Mazzucato 2013b; Mazzucato and Penna, 2014). While mission-oriented programs are intrinsically dynamic, with feedback loops between missions and achievements, the tools used to evaluate such public policies have remained static, coming from the market failure theory toolbox (despite the fact that many studies draw on the innovation systems perspective from evolutionary economics). For these reasons, mission-oriented policy research is currently confined to a small area of policy research and practice, and has had very little impact on how economists understand the role of public policy. One particular limitation is that this stream of research has continued to assume that innovation and dynamism are housed inside firms, with the state only playing a facilitating role. A new framework must seek to address the mismatch between theory and practice by developing a new economic policy framework that can explain and justify the kinds of mission-oriented policies that have led to the shaping and creation of new markets, and not to the correction of markets.

\section{b) Development Economics: Developmental Network States}

Work on the developmental state, a concept from a small group of development economists, has revealed the importance of the 'visible hand' of the state in industrialization and technological change (Wade, 1990; Chang, 2002; Amsden, 2001). More recently, this literature has also emphasized the importance of a developmental network state; that is, a decentralized network of different types of state agencies that can foster innovation and development. While significant 
attention has been devoted to the role of large agencies or institutions (such as DARPA or the $\mathrm{NIH}$ ) in historical mission-oriented projects, it is only recently that considerable focus has been placed on the broader network of structures, actors, strategies and agencies, such as intelligence distributed amongst actors and institutions, flat organizational structures, flexibility, and customization (Perez, 2002). Indeed, many successful cases of innovation and technology policy strategies have been carried out by networks of decentralized public institutions, which have focused not on creating individual 'national champion' firms, but on establishing a constellation of innovative firms (O'Riain, 2004). This has been the case in East Asia, Finland, Israel, Taiwan, and even in Silicon Valley in the US (Block and Keller, 2011). Such successful policies have covered a wide range of measures, including R\&D support, training, support for marketing and export, funding programs (including early-stage venture capital), networking and brokerage services, building of facilities and clusters (so-called science parks), and fostering industrial ties. Although not all networks of decentralized institutions were driven by a technological mission, this has been the case with the networks fostered by DARPA (driven by security missions) or the $\mathrm{NIH}$ (health/cure of diseases), two of the most successful cases of mission-oriented initiatives. In the case of East Asia, the implicit mission was industrial development and 'catching up' (Chang, 2002).

From this alternative view, economic development is not the result of natural (exogenous and exante) competitive advantages, but of the endogenous creation of new opportunities that lead to the establishment of competitive advantages. This requires discovering the cost structure of an economy in order to identify which types of goods and services that already exist in world markets can be produced in a domestic economy at low cost (Rodrik, 2004). The state plays a central coordinating role in this discovery process, and often represents a lead agent in economic development efforts. To do this, the state may work as an agency to nurture nascent or knowledge-intensive firms (infant-industry promotion); promote strategic trade (such as import substitution) and financial leverage; prioritize investments in existing strategic sectors (reinforcing comparative advantages); create national champions; and provide coherence to economic policies (Wade, 1990; Amsden, 2001; Chang, 2002; Reinert, 2007; Falck et al., 2011). While MFT may explain the need for some of these activities (for example, infant-industry promotion as a result of adverse selection by private investors), the state does much more by fulfilling this developmental role than just provide financial capital to fix failures. Because economic development is an endogenous process, the state provides social capital, coordinates initiatives and public-private partnerships, fosters synergies, and promotes the introduction of 'new combinations' that create Schumpeterian rents (Reinert, 2007).

\section{c) Evolutionary Economics: Technological Trajectories and Techno-Economic Paradigm Shifts}

Schumpeter warned that the methodology of neoclassical economics (based on 'comparative statics'; that is, the comparison of static equilibrium situations) and its treatment of technical change as an exogenous process-both of which MFT adopts-were "not sufficient to explain the real development of the economy" (Schumpeter, 2002 [1912], p. 97). Evolutionary economists following the Schumpeterian tradition aimed to "open the black box of technical change" (Rosenberg, 1982) by means of a different methodology (based on historical analysis and empirical evidence) in order to understand the process that links technical change (innovation), economic growth and development. Key concepts developed in evolutionary economics are those of 'technological paradigms' and 'technological trajectories' (Dosi, 1982; Nelson and Winter, 1982), which reveal the limitation of market forces in providing a direction to economic development. A technological paradigm has a threefold definition (Dosi, 1982, p. 148): it is an outlook of the relevant productive problems confronted by firms (as producers of technologies or innovators); it represents a set of procedures (routines) of how these problems shall be approached; and it defines the relevant problems and associated knowledge necessary for their solution. A technological trajectory, in turn, represents the direction of progress within a technological paradigm. Therefore, technology development is a problem-solving activity, and a technological paradigm "embodies strong prescriptions on the directions of technical change" (p. 152). This is why market signals are limited in terms of providing direction to techno-economic development; they only work within the parameters of the paradigm, which means they influence the rate of change more than its direction. When two or more technological paradigms compete, markets may influence which one is selected (the one which minimizes costs). Once established, however, 
paradigms have a powerful 'exclusion effect', whereby some technological possibilities are discarded because they are incompatible with the prevailing paradigm and are therefore 'invisible' to agents. Thus, a techno-economic system of innovation may be locked into a self-reinforcing, path-dependent trajectory (Dosi and Nelson,1994). This becomes a problem if the trajectory being followed (or the paradigm itself) is inferior or suboptimal to what could be achieved with technologies that transgress the paradigm (or with a different paradigm).

Perez (2002) expanded the notion of technological paradigm to 'techno-economic paradigm' in order to account for the non-technological forces (economic and social institutions) that characterize certain periods of capitalist history, and affect both the economic and social systems. Her theory of 'techno-economic paradigm' shifts is a historical perspective on the long-waves of development that accompany technological revolutions. "A techno-economic paradigm is, then, a best-practice model made up of a set of all-pervasive generic technological and organizational principles, which represent the most effective way of applying a particular technological revolution and of using it for modernizing and rejuvenating the whole of the economy" (Perez, 2002, p. 15). When a new technological revolution emerges, the socio-economic system remains stuck within the bounds of the previous paradigm. This renders market forces incapable of directing the system towards the new paradigm and stifles the modernizing and rejuvenating potential of the new revolution. In other words, there are mismatches between elements of the social and technoeconomic systems (for example, social expectations, R\&D routines, tax regimes, labor regulations). In order to overcome these mismatches, it is necessary to build new institutions that favor the diffusion of the new paradigm. In all previous technological revolutions, governments have led the process of institution-building that allowed new techno-economic paradigms to replace the old ones. Perez (2002) specifically pointed to the role of public policy in allowing the full deployment of technological revolutions, such as the effect of suburbanization on the ability of the mass production revolution to diffuse throughout the economy.

This stream of research on technological and techno-economic paradigms highlights the importance of cognition when establishing the direction of technological change. Paradigms are powerful enabling and constraining institutions that favor certain directions of techno-economic development and obstruct others. In order to redirect techno-economic development on a new, qualitatively different route, a paradigm shift is required that will avoid the constant renewal of prevailing trajectories, which occurs if market forces provide directionality to the system. From this perspective, the state has a crucial role to play in terms of creating a new vision that will coordinate cognitive efforts of different (public and private) agents and direct their action to areas beyond the existing paradigm. Green innovation can be understood as a redirection of the full deployment of the IT revolution (Mazzucato and Perez, 2014). To be effective at providing the direction of change, a vision must be created and shared. Stirling (2008) rightly focuses on the role of bottomup participatory processes to ensure directionality is taken seriously and shared amongst actors.

\section{d) The Entrepreneurial State: The State as Lead Risk-Taker and Investor in the Economy}

Private business investment in innovation is driven not by costs, but by perceptions of technological and market opportunities. Studies in industry dynamics have documented that there is a weak relationship between entry of new firms into industries and the current levels of profits in those industries (Vivarelli, 2013). Firm entry appears to be driven by expectations about future growth opportunities, even when such expectations are overly optimistic (Dosi and Lovallo, 1998). Historically, such technological and market opportunities have been actively shaped by government spending - what I refer to as 'the entrepreneurial state' — that is, a willingness to invest in, and sometimes imagine from the beginning, new high-risk areas before the private sector does (Mazzucato, 2013a). This is not to say that the private sector is not important, because it most certainly is; instead, this line of thought emphasizes the way in which, historically, business has tended to enter new sectors only after the high uncertainty (for example, areas of capital intensity, and areas of high risk) has been absorbed by the public sector. This was the case with the IT revolution (Block and Keller, 2011), the biotechnology industry (Lazonick and Tulum, 2011), nanotechnology (Motoyama et al., 2011), and for the emerging clean tech sector (Mazzucato and Penna, 2014).

In the book The Entrepreneurial State: Debunking Public vs. Private Sector Myths (Mazzucato, 2013a), I described the risk-taking role the state has played in the few countries that have 
achieved innovation-led growth. I focused on the way in which the state played a lead investment role across the entire innovation chain, from basic research to early-stage seed financing of companies; this role is not captured by a purely public good justification for investments. Figure 2 shows the presence of the kinds of mission-oriented agencies (in orange), discussed in section 3a above, that have been present along the entire innovation chain. The arrows indicate that it is necessary for such agencies to be flexible and able to nurture feedback processes between different stages of the chain (precisely due to the non-linear types of feedback processes emphasized by evolutionary economics; see section 3c). The systems of innovation literature has sometimes overlooked the immense risk-taking that such agencies absorb, with many of the innovation attempts, ending in failure. ARPA-E is a testament to this process. This organization is currently attempting to emulate, in the area of renewable energy, the kind of radical innovation that its sister organization in the Department of Defense, DARPA, has engendered in computing. Cheryl Martin, ARPA-E's former director, stated that ARPA-E welcomes uncertainty: "We are concerned with framing the challenges of energy in new ways, inviting new eyes, and novel ideas to the table. We look across the entire spectrum of the energy sector for ideas and connections, as it is very dynamic. Think of what was 'known' in energy just five years ago-some of those truths are very different now, and will change and evolve as we move into the future" (Mazzucato and Penna, 2015, p. 106).

Ignoring the high risk and uncertainty that the state has absorbed has caused the fruits of innovation-led growth to be privatized, even though the underlying risk was socialized. It is usually assumed that the returns to the state will occur through higher tax income. However, I have argued that this return-generating system is broken and suggested that more thinking is needed regarding concrete ways to generate direct mechanisms for the state in order to create a 'revolving fund'. Such mechanisms will make it possible to cover inevitable losses (innovation is uncertain) and fund subsequent rounds, as is the case with private venture capital. Future research should evidence from across the world on how such return-generating mechanisms are used and consider the implications of the state as a public venture capitalist (Rodrik, 2015), which can follow a portfolio approach that allows the returns from the successes to cover the losses from the failures, with enough left over to cover the next round of investments. How to do this, while retaining a mission-oriented perspective (not limited by cost-benefit analysis), is a key challenge.

Figure 2 Public and private investments along the innovation chain

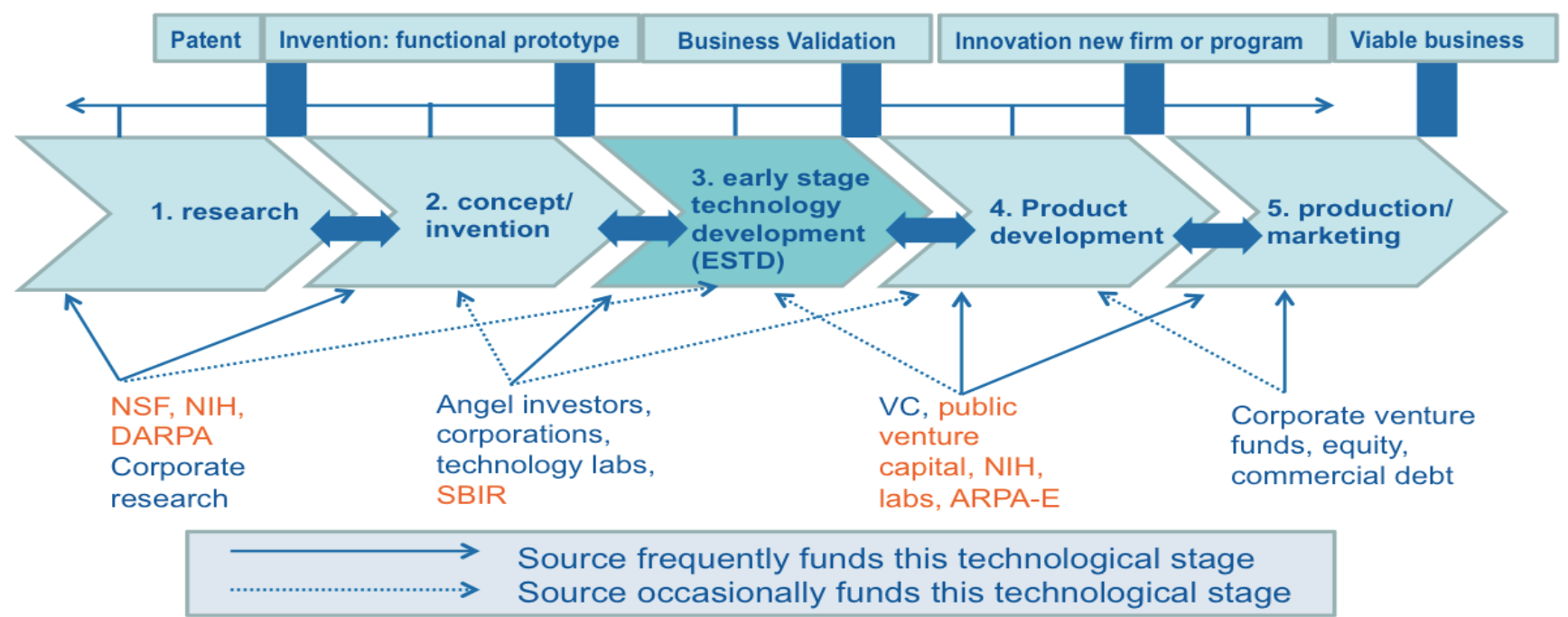

(Source: Author's addition of public agencies to underlying figure by Auerswald and Branscomb 2003. NSF National Science Foundation, NIH National Institutes of Health, DARPA Defense Advanced Research Projects Agency, SBIR Small Business Innovation Research Program, ARPA-Energy.) 


\section{BEYOND MARKET FAILURE: ROUTES, ORGANIZATION, ASSESSMENT, AND REWARDS}

This section brings together key concepts from the four heterodox frameworks reviewed above, drawing especially on the empirical research conducted within these frameworks, in order to provide a new theoretical conceptualization for guiding state action to tackle transformational change.

Directionality: understanding the role of policy as setting the direction of change. Policies that aim to correct markets assume that once the sources of the failure have been addressed, market forces will efficiently direct the economy to a path of growth and development. However, markets are "blind" (Dosi, 1982) and the direction of change provided by markets often represents suboptimal outcomes from a societal point of view. This is why, in addressing societal challenges, states have sometimes led the process and provided the direction towards new techno-economic paradigms, which did not emerge spontaneously out of market forces. Governments made direct investments in the technologies that enabled the mass production and IT revolutions to emerge, and formulated bold policies that allowed them to be fully deployed throughout the economy (Ruttan, 2006; Block and Keller, 2011). Examples include suburbanization policies that allowed mass production to affect the productivity of all sectors, and the military motives that allowed IT to begin its deployment phase (Perez, 2002). Furthermore, in the IT revolution, and even in the emerging clean tech revolution, government not only funded the actual technologies (such as mainframes, the Internet, wind and solar power, and fuel cells), but also provided early-stage funding to companies that risk-averse private finance would not, and devised special tax credits that favored certain activities more than others (Mazzucato, 2013a). These facts seem to point to a different analytical problem facing policy makers: namely, choosing whether the right role is to direct or stand back, understanding how particular 'directions' and routes can be picked, and determining how to mobilize and manage activities that can lead to the achievement of dynamic social and technological challenges.

The problem is not whether or not to pick a direction, but how to learn from the successful picking of the past, and to enable the directions picked to be broad enough to allow bottom-up exploration, discovery and learning. This is sometimes referred to as 'smart specialization' (Foray, David and Hall, 2009). Smart specialization is explicitly a results- and outcome-oriented agenda, not an inputor outputs-oriented one (Rodrik, 2004). However, the fact that it has hitherto been based on a market failure framework means that smart specialization is, at best, seen as a 'discovery' process for stakeholders and policy-designers to jointly identify bottlenecks, market failures, and missing links. Smart specialization has not addressed the way in which innovation-led growth in places like Silicon Valley actually happened. Doing so requires not only the identification of missing links, but the formation of concrete strategies towards producing market landscapes that simply did not exist in the past. It also requires 'tilting' the playing field in the direction pursued, rather than 'leveling' it (Mazzucato and Perez, 2015).

Organization: transform public organizations into ones that welcome learning, experimentation and self-discovery. If brought to its extreme, as advocated by critics from Public Choice and the Chicago School of Economics, MFT calls for the state to intervene as little as possible in the economy, in a way that minimizes the risk of government failure, from crowding out to cronyism and corruption. This view requires a structure that insulates the public sector from the private sector (to avoid issues such as agency capture) and has resulted in a trend of 'outsourcing' that often rids government of the knowledge capacities and capabilities (in relation to IT, for example) that are necessary for managing change (Kakabadse and Kakabadse, 2002). Studies have examined the influence that outsourcing has on the ability of public institutions to attract top-level talent with the relevant knowledge and skills to manage transformative missionoriented policies. Without such talent and expertise it is nearly impossible for the state to fulfill its role of coordinating and providing direction to private actors when formulating and implementing policies that address societal challenges. In order to promote transformation of the economy, by shaping and creating technologies, sectors, and markets, the state must organize itself so that it has the intelligence (policy capacity) to think big and formulate bold policies. If the state is essential to the process of transformative technological and socio-economic change, then it is also essential to understand the appropriate structure of public organizations. Innovation is subject to extreme 
uncertainty, which creates the need for both patience ("patient long-term capital", Mazzucato, $2013 \mathrm{~b}$ ) and the ability to experiment and explore the underlying landscape (Rodrik, 2004). Therefore, a crucial element in organizing the state for its 'roaring' role is absorptive capacity (Cohen and Levinthal, 1990), which enables governmental agencies to learn in a process of investment, discovery, and experimentation.

The size of the state, and hence its ability to earn back a return, either through tax or other means to fund its size, depends on its purpose. If the role of the state is simply to correct market failures and perform a subsidiary role to private initiative, it is sufficient to have little more than a minimal state that performs only unanimously approved functions, such as guaranteeing property rights and enforcing contracts (Atkinson and Stiglitz, 1980). The use of market failure as a diagnostic tool for public policies became prominent in the 1980s and was accompanied by public administration reform initiatives that sought to 'modernize' (often through downsizing) the state apparatus (Pollitt and Bouckaert, 2004), often in line with tenets from public choice theory (Buchanan, 2003). If policy-making is seen (i) as a non-probabilistic risk-taking process surmounted by uncertainty about technical and economic outcomes (Mazzucato, 2013a); (ii) as a process of experimentation and discovery (Hirschman, 1967; Rodrik, 2004); and (iii) as a continuous process of learning that leads to some successes and failures measured beyond static monetary analysis of the costs and benefits attached to quantifiable outcomes, then the size of the state apparatus and purely economic efficiency of the state are the wrong focuses for organizing the state.

The above point suggests that the key concern should be to establish which skills/resources, capabilities and structures are useful to increase the chances that a state organization will be effective, both at learning and at establishing symbiotic partnerships with the private sector, and ultimately succeed in implementing mission-oriented and transformative policies. Public and private organizations must re-rethink their roles when working together. Public-private partnerships have often limited the public part in 'de-risking' the private part. This ignores the capabilities and challenges involved in public sector risk taking. De-risking assumes a conservative strategy that minimizes the risks of picking losing projects and maximizes the probability of picking winners, but by adopting a portfolio approach for its investments (Rodrik, 2013). In such an approach, success from a few projects can cover the losses from many projects, and the state also learns from its losing investments (Mazzucato, 2013a). In this approach, the matching between failures and fixes is less important than having an institutional structure that ensures that winning policies provide enough 'rewards' to cover the losses, and that losses are used as learning cases to improve and renew future policies. Research on the developmental state (Block and Keller, 2011) suggests that these goals are best achieved not through top-down policies, but through a decentralized structure in which the organization(s) involved remain nimble, innovative, and dynamic from within. This strand of thinking can benefit from looking at the ways in which public-private partnerships were created when seeking the joint creation of new products and services, including vaccines (Chataway et al., 2007).

Evaluation: transforming static metrics into dynamic ones. The market failure framework has developed concrete indicators and methods to evaluate government investments, which stem directly from the framework itself, usually through a cost-benefit analysis that estimates whether the benefits of public intervention compensate for the costs associated with the market failure and with the implementation of the policy (including governmental failures). However, there is a mismatch between the intrinsically dynamic character of economic development and the static tools used to evaluate the role of the state in the process.

The mainstream diagnostics and evaluation approach (based on MFT) involves identifying the sources of the market failure and targeting policy interventions on their correction. This approach mostly entails ex-ante considerations about administrative and fiscal requirements and politicaleconomic consequences of the intervention (Rodrik, 2004). Such an exercise usually consists of the following steps:

- An ex-ante cost-benefit analysis that weighs up the costs of the failure, the (private and social) benefits from addressing it, and the costs and risks of government failure.

- An ex-ante identification of sources of market failures and of second-best policy tools to address them. 
- An ex-ante diagnostic of the principal-agent structure that best avoids governmental capture by private interests (insulation/autonomy) and forces private agents to do what the principal (government) wants.

- An ex-post evaluation of the outcomes of the intervention vis-à-vis the ex-ante quantifiable prediction of the likely outcomes of the intervention.

This toolbox for evaluating public policies and investments that aim to address societal challenges is limited because doing so represents a static exercise of evaluation of an intrinsically dynamic process. Not allowing for the possibility that government can transform and create new landscapes that did not previously exist affects the ability to measure such impact; economists often resort to analyzing the public sector as an inefficient private sector (Mazzucato, 2013a). This is evident not only in the area of innovation, but also for public services. This situation then leads to accusations of government crowding out businesses, which implies that the areas that government moves into could have been areas for business investment. Such claims are best defended through a crowding in argument, which rests on showing how government investments create a large national output (the savings) that can be shared between private and public investors. However, this defense does not account for the fact that businesses are risk-averse and unwilling or unable to transform existing and create new landscapes (which is about creating new pies, not increasing existing ones). Without indicators for such transformative action, the toolbox affects the government's ability to know whether it is simply operating in existing spaces or if it is making new things happen that would not have happened anyway (its 'additionality'). This often leads to investments that are overly narrow or directed within the confines of the boundaries set by business practices of the prevailing techno-economic paradigm (Abraham, 2010).

Given the above, it is crucial to develop a new toolbox and indicators for evaluating and measuring the degree to which state investments open up and transform sectoral and technological landscapes, rather than operating within existing ones. The indicators must take into account the underlying risk and uncertainty in transforming such landscapes.

Policy exploration inevitably involves making mistakes. A fundamental part of the process is to differentiate the process of trial and error, from cases where rigid public institutions persistently follow the wrong path. On one hand, it is necessary to have the ability to take risks, and accept the consequences; on the other hand, it is also essential to create internal checks and balances to ensure that a consistently wrong path is not pursued. But what do we mean by 'wrong'? Here it is essential to develop a notion of public value that is wider than just the notion of the public good (which has been used to limit the legitimate areas for public intervention).

Risks and Rewards: building symbiotic private-public partnerships. Market failure theory says little about cases in which the state is the lead investor and risk taker in capitalist economies. Having a vision of which way to drive an economy requires direct and indirect investment in particular areas, not just creating the conditions for change. Crucial choices must be made, the fruits of which will create some winners, but also many losers. For example, the Obama administration in the US recently provided large guaranteed loans to two green-tech companies, Solyndra ( $\$ 500$ million) and Tesla Motors ( $\$ 465$ million). While the latter is often glorified as a success story, the former failed miserably and became the latest example, used widely by economists, the media, and taxpayers (who ultimately paid for Solyndra) of government being unable to pick winners (Wood, 2012). This situations suggests that it is necessary for such investments to be made in a portfolio approach with some of the upside gains covering the downside losses. In other words, if the public sector is expected to fill in for the lack of private venture capital (VC) money going to early-stage innovation, it should at least be able to benefit from the wins, as private VC does. Otherwise, the funding for such investments cannot be secured.

Nonetheless, questions about risks and rewards depend on the underlying framework through which public investment is justified. In a market-shaping framework, does government deserve to retain equity more than in a market failure framework? Are taxes currently bringing back enough return to government budgets to fund high-risk investments that will probably fail? Using a portfolio approach to public investments (Rodrik, 2013) means being able to reap a reward from the wins, in order to fund the losses and the next round. Such direct return-generating mechanisms must be explored, including retaining equity, golden share of the IPR, and income-contingent loans (Mazzucato, 2013). 
In order to share risks and rewards, it is also necessary to ensure that private sector commitment to innovation increases. As a recent MIT report on the innovation economy emphasized, contemporary capitalism is missing the kind of large-company engagement that Xerox Parc and Bell Labs exhibited in the past. In looking at the strengths and weaknesses of the US innovation system and the causes of relative decline of manufacturing in America, that study sought to understand why the development of promising innovations is stalling or simply moving abroad before reaching commercial scale; this problem is even more central to the UK economy. One of the reasons that the study identified is the fact that large private R\&D centers (such as Bell Labs, Xerox PARC, and Alcoa Research Lab) have mostly disappeared. Long-term basic and applied research is no longer part of the strategy of big business, as corporate R\&D now focuses on shortterm needs (MIT, 2013). Recent examples of the extreme financialization of large corporations, in areas as diverse as pharmaceuticals, IT, and energy, is putting the development of proper innovation eco-systems at risk (Lazonick and Mazzucato, 2013). Financialization is most evident in the amount of profits being used to boost share prices (and stock options, hence executive pay) through such activities as share buybacks. Share buybacks by Fortune 500 companies totaled $\$ 3$ trillion dollars between 2004-2014-the most worrying aspect is the degree to which such expenditure has outpaced R\&D (Lazonick, 2014). Accordingly, the risk-reward balance must consist not only of allowing the public sector to reap its deserved reward for winning investments (to cover the inevitable losses, and the next round of investments), but also to increase the actual risks taken by large companies in the innovation process. This means that innovation policy and policies around financial reform and corporate governance should be brought together so that the eco-systems of innovation (and associated private-public partnerships) are more symbiotic and less parasitic.

\section{CONCLUSION}

This paper has considered the limitations of the market failure framework that continues to guide innovation policy. It has argued that putting innovation at the center of growth policy requires an emphasis on shaping and creating markets rather than just fixing them. To facilitate this changethe goal of this think piece-the paper has considered insights from alternative (heterodox) literatures in the economics of innovation on this market creation process.

Considering the need for government policy to transform, be catalytic, and create and shape markets rather just fix them helps reframe the key questions of economic policy from static ones that deal with crowding out and picking winners to more dynamic ones that help form the types of public-private interactions that can create new innovation and industrial landscapes. From this perspective, governments must not just pick different technologies or sectors, but ask what they want from those sectors. In the same way that putting a man on the moon required many sectors to interact, the green direction being debated today requires all sectors to change. Green is not only about wind, solar, and biofuels, but also about new engines, new maintenance systems, and new ways of thinking about product obsolescence (Mazzucato and Perez, 2014). The point is not to prescribe specific technologies, but to provide directions of change around which bottom-up solutions can then experiment. As Stirling $(2014$, p. 2) recently put it: "The more demanding the innovation challenges like poverty, ill health or environmental damage, the greater becomes the importance of effective policy. This is not a question of 'picking winners'-an uncertainty-shrouded dilemma which is anyhow equally shared between public, private and third sectors. Instead, it is about engaging widely across society, in order to build the most fruitful conditions for deciding what 'winning' even means".

It is also important to remember that context is important, both nationally and sectorally. An overly centralized state may end up defining the direction of innovation policy in a rigid way. This is why it is so important to learn from the experience of a decentralized developmental network state (Block and Keller, 2011). In other cases, smaller states (both the BRIC countries and small northern OECD economies) may find it more difficult to create so many networked institutions, which can define and shape agendas in a decentralized way. However, their smaller size may actually enable them to develop flexible public institutions that are able to adapt to change. For smaller countries, it 
may also be that the role of the state in shaping innovation trajectories is more like a foresight capability that seeks to anticipate what will emerge in the future and anticipate what is beyond the recognition, time-horizons, and capabilities of their private sector. Singapore, for example, invests immensely in such foresight activities through its Centre for Strategic Futures, which plays a pivotal role in its innovation policy (Habegger, 2010). Researchers (Breznitz and Ornston, 2013) have also studied the experience of small peripheral agencies, such as Finland's Sitra, which can think outside the box to a greater extent than their larger counterparts (such as Tekes in Finland). Context is also important with regard to sectors, both in terms of the specific life-cycle they are passing through (Klepper, 1997) and the particular phase during a technological revolution and/or 'long wave' (Perez, 2009).

In this paper, having considered the multitude of available options, I have argued that government would benefit from adopting a portfolio approach to public investments in innovations, nurturing the explorative, plural, and trial-and-error aspect of change. Doing so requires thinking not only about technological change in a new way, but also organizational change. This involves building the public agencies of the future with creative, adaptive, and explorative capacity.

In sum, this paper has argued that in order to approach the innovation challenge of the future, we must open up the discussion, moving away from the narrow worry about picking winners and crowding out, towards a broader focus on the four following interlinked dynamic questions:

- Directions. How can public policy be understood in terms of setting the direction and route of change; that is, shaping and creating markets rather than just fixing them? What can be learned from the ways in which directions were set in the past, and how can we stimulate more democratic debate about such directionality?

- Organizational change. How should public organizations be structured so that they accommodate the risk-taking and explorative capacity, and the capabilities needed to envision and manage contemporary challenges?

- Evaluation. How can an alternative conceptualization (to standard market failure theory) of the role of the public sector in the economy translate into new indicators and assessment tools for evaluating public policies, beyond the micro-economic cost/benefit analysis? How does this alter the crowding in/out narrative?

- Risks and Rewards. How can this alternative conceptualization be put into practice so that it frames investment tools in such a way that they not only socialize risk, but also have potential to socialize the rewards that enable smart growth to also be inclusive growth? 


\section{REFERENCES}

Abraham, J. (2010). Pharmaceuticalization of society in context: Theoretical, empirical and health dimensions. Sociology, 44(4), 603-622.

Amsden, A. H. (2001). The rise of "the rest": Challenges to the West from late-industrializing economies. Oxford University Press.

Anadón, L. D. (2012). Mission-oriented R\&D institutions in energy between 2000 and 2010: A comparative analysis of China, the United Kingdom, and the United States. Research Policy, 41(10), 1742-1756.

Angell, M. (2005). The truth about the drug companies: How they deceive us and what to do about it. New York. Random House.

Arrow, K. (1951). An extension of the basic theorems of classical welfare economics. Paper presented at the Second Berkeley Symposium on Mathematical Statistics and Probability, Berkeley.

Arrow, K., \& Lind, R. C. (1970). Uncertainty and the evaluation of public investment decisions. The American Economic Review, 364-378.

Aschauer, D. A. (1989). Does public capital crowd out private capital? Journal of Monetary Economics, 24(2), 171-188.

Atkinson, A. B., \& Stiglitz, J. E. (1980). Lectures on public economics. London. McGraw-Hill Book Co.

Auerswald, P. E., \& Branscomb, L. M. (2003). Valleys of death and Darwinian seas: Financing the invention of innovation transition in the United States. Journal of Technology Transfer, 28(3-4), 227-239.

Bator, F. M. (1958). The anatomy of market failure. The Quarterly Journal of Economics, 72(3), $351-379$.

Block, F. L., \& Keller, M. R. (2011). State of innovation: The U.S. government's role in technology development. Boulder, CO: Paradigm Publishers.

Breznitz, D., \& Ornston, D. (2013). The revolutionary power of peripheral agencies explaining radical policy innovation in Finland and Israel. Comparative Political Studies.

Buchanan, J. M. (2003). Public choice: The origins and development of a research program. Champions of Freedom, 31, 13-32.

Cantner, U., \& Pyka, A. (2001). Classifying technology policy from an evolutionary perspective. Research Policy, 30(5), 759-775.

Chang, H. J. (2002). Kicking away the ladder: Development strategy in historical perspective. London. Anthem Press.

Chataway, J., Brusoni, S., Cacciatori, E., Hanlin, R., \& Orsenigo, L. (2007). The international AIDS vaccine initiative (IAVI) in a changing landscape of vaccine development: A public/private partnership as knowledge broker and integrator. The European Journal of Development Research, 19(1), 100-117.

Chiang, J. T. (1991). From 'mission-oriented' to 'diffusion-oriented' paradigm: The new trend of US industrial technology policy. Technovation, 11(6), 339-356.

Coase, R. H. (1960). The problem of social cost. Journal of Law \& Economics, 3(1), 1-44.

Cohen, W. M., \& Levinthal, D. A. (1990). Absorptive capacity: A new perspective on learning and innovation. Administrative Science Quarterly, 35(1).

Crouch, C. (2004). Post-Democracy, Polity, 254-285, Cambridge, MA

Dosi, G. (1982). Technological paradigms and technological trajectories: A suggested interpretation of the determinants and directions of technical change. Research Policy, 11(3), $147-162$.

Dosi, G., \& Lovallo, D. (1998). Rational entrepreneurs or optimistic martyrs? Some considerations on technological regimes, corporate entries, and the evolutionary role of decision biases. In R. Garud, P. Nayyar \& Z. Shapiro (Eds.), Foresights and oversights in technological change (pp. 41-68). Cambridge, England: Cambridge University Press.

Dosi, G., \& Nelson, R. R. (1994). An introduction to evolutionary theories in economics. Journal of Evolutionary Economics, 4(3), 153-172.

European Commission. (2011). Horizon 2020: The framework programme for research and innovation (2014-2020). Brussels, European Commission. 
Falck, O., Gollier, C., \& Woessmann, L. (2011). Arguments for and against policies to promote national champions. In O. Falck, C. Gollier, \& L. Woessmann (Eds.), Industrial policy for national champions (pp. 3-9). Cambridge, MA: MIT Press.

Foray, D., David, P. A., \& Hall, B. (2009). Smart specialization: The concept.[in:] Knowledge for growth. Prospects for science, technology and innovation. Selected papers from Research Commissioner Janez Potočnik's Expert Group, 20.

Foray, D., Mowery, D., \& Nelson, R. R. (2012). Public R\&D and social challenges: What lessons from mission R\&D programs? Research Policy, 41(10), 1697-1902.

Freeman, C. (1995). The 'National System of Innovation' in historical perspective. Cambridge Journal of Economics, 19(1), 5-24.

Freeman, C., \& Soete, L. (1997 [1974]). The economics of industrial innovation (3rd ed.). Cambridge, MA. MIT Press.

Friedman, B. M. (1979). Crowding out or crowding in? The economic consequences of financing government deficits. Brookings Papers on Economic Activity, 3, 593-654.

Giavazzi, F., \& Pagano, M. (1990). Can severe fiscal contractions be expansionary? Tales of two small European countries. In O. J. Blanchard \& S. Fischer (Eds.), NBER macroeconomics annual 1990 (Vol. 5, pp. 75-122). Boston. MIT Press.

Habegger, B. (2010). Strategic foresight in public policy: Reviewing the experiences of the UK, Singapore, and the Netherlands. Futures, 42(1), 49-58.

Hirschman, A. O. (1967). Development projects observed. Washington DC. Brookings Institution Press.

Judt, T. (2011). III fares the land: A treatise on our present discontents. Penguin.

Kakabadse, A., \& Kakabadse, N. (2002). Trends in outsourcing: Contrasting USA and Europe. European Management Journal, 20(2), 189-198.

Keynes, J. M. (1926). The end of laissez-faire. London, England: Prometheus Books.

Klepper, S. (1997). Industry life cycles. Industrial and Corporate Change, 6, 145-182.

Krueger, A. O. (1974). The political economy of the rent-seeking society. The American Economic Review, 64(3), 291-303.

Lazonick, W., \& Tulum, O. (2011). US biopharmaceutical finance and the sustainability of the biotech business model. Research Policy, 40(9),1170-1187.

Lazonick W. (2014). Profits without prosperity. Harvard Business Review, 92(9), 46-55.

Lazonick, W., \& Mazzucato, M. (2013). The risk-reward nexus in the innovation-inequality relationship: Who takes the risks? Who gets the rewards? Industrial and Corporate Change, 22, 1093-1128.

Lundvall, B. A. (1992). National innovation system: towards a theory of innovation and interactive learning. Pinter, London.

Mazzucato, M. (2013a). The entrepreneurial state: Debunking the public vs. private myth in risk and innovation. London: Anthem Press.

Mazzucato, M. (2013b). Financing innovation: Creative destruction vs. destructive creation. Industrial and Corporate Change, 22(4), 851-867.

Mazzucato, M., \& Penna, C. C. R. (2014). Beyond market failures: State investment banks and the 'mission-oriented' finance for innovation. SPRU Working Paper Series, 21.

Mazzucato, M., \& Penna, C. C. R. (Eds) (2015). Mission-oriented finance for innovation: New ideas for investment-led growth. London, England: Pickering \& Chatto Publishers. Rowman \& Littlefield.

Mazzucato, M., \& Perez, C. (2014). Innovation as growth policy. SPRU Working Paper Series, 13.

Massachusetts Institute of Technology (2013). A preview of the MIT production in the 'Innovation Economy Report', edited by Richard M. Locke and Rachel Wellhausen, mit.edu, 22 February. Available from http://web.mit. edu/press/images/documents/pie-report.pdf (accessed 25 July 2014).

Motoyama, Y., Appelbaum, R., \& Parker, R. (2011). The national nanotechnology initiative: Federal support for science and technology, or hidden industrial policy? Technology in Society, 33(12), 109-118.

Mowery, D. C. (2010). Military R\&D and innovation. In B. H. Hall \& N. Rosenberg (Eds.), Handbook of the economics of innovation (Vol. 2, pp. 1219-1256). 
Mowery, D. C., Nelson, R. R., \& Martin, B. R. (2010). Technology policy and global warming: Why new policy models are needed (or why putting new wine in old bottles won't work). Research Policy, 39(8), 1011-1023.

Nelson, R. R., \& Winter, S. G. (1982). An evolutionary theory of economic change. Cambridge, MA: Belknap Press.

O'Riain, S. (2004). The politics of high tech growth: Developmental network states in the global economy. Boston. Cambridge University Press.

Perez, C. (2002). Technological revolutions and financial capital: The dynamics of bubbles and golden ages. Cheltenham, England. Edgar Elgar.

Perez, C. (2010). The financial crisis and the future of innovation: A view of technical change with the aid of history. TUT Ragnar Nurkse School of Innovation and Governance Working Paper Series, 28.

Polanyi, K. (2001 [1944]). The great transformation: The political and economic origins of our time (2nd Beacon Paperback ed.). Boston, MA: Beacon Press.

Pollitt, C., \& Bouckaert, G. (2004). Public management reform: A comparative analysis (2nd ed.). Oxford. Oxford University Press.

Reinert, E. S. (2007). How rich countries got rich and why poor countries stay poor. London, England: Constable.

Rodrik, D. (2004). Industrial policy for the twenty-first century. John F. Kennedy School of Government Working Paper Series, rwp04-047.

Rodrik, D. (2013). Green industrial policy. Princeton University Working Paper.

Rodrik, D. (2014), From Welfare State to Innovation State, Project Syndicate http://www.projectsyndicate.org/commentary/labor-saving-technology-by-dani-rodrik-2015-01 (accessed 3/3/15)

Rosenberg, N. (1982). Inside the black box: Technology and economics. Boston. Cambridge University Press.

Ruttan, V. W. (2006). Is war necessary for economic growth? Military procurement and technology development. University of Minnesota, Department of Applied Economics.

Sampat, B. N. (2012). Mission-oriented biomedical research at the NIH. Research Policy, 41(10), $1729-1741$.

Sanderson, H., \& Forsythe, M. (2013). China's superbank: Debt, oil and influence - How China Development Bank is rewriting the rules of finance. Singapore: John Wiley \& Sons.

Schumpeter, J. A. (2002 [1912]). Seventh chapter of the theory of economic development. Industry and Innovation, 9(1-2), 93-145.

Shellenberger M., Nordhaus, T., Trembath, A., \& J. Jenkins (2013). Where the Shale Gas

Revolution Came From: Government's Role in the Development of Hydraulic Fracturing in Shale

http://thebreakthrough.org/images/main image/Where the_Shale_Gas_Revolution_Came_From2.

pdf (accessed 1/1/5).

Soete, L., \& Arundel, A. (1993). An integrated approach to European innovation and technology diffusion policy: A Maastricht memorandum. Luxembourg: Commission of the European Communities, SPRINT Programme.

Stern, N. H. (2006). The economics of climate change (Stern Review). HM Treasury.

Stiglitz, J. (1974). Growth with exhaustible natural resources: The competitive economy. Review of Economic Studies, 41(5), 139-152.

Stiglitz, J. (1991). The invisible hand and modern welfare economics. NBER Working Paper, 3641.

Stiglitz, J., \& Weiss, A. (1981). Credit rationing in markets with imperfect information. American Economic Review, 3(71), 393-410.

Stirling, A. (2008). "Opening up" and "closing down" power, participation, and pluralism in the social appraisal of technology. Science, Technology \& Human Values, 33(2), 262-294.

Stirling, A. (2014). Making choices in the face of uncertainty. Themed Annual Report of the Government Chief Scientific Adviser, Chapter 2 (June). Draft mimeo.

Tullock, G., Seldon, A., \& Brady, G. L. (2002). Government failure: A primer in public choice. Washington, DC: Cato Institute.

Verspagen, B. (2006). Innovation and economic growth. In J. Fagerberg, D. C. Mowery, \& R. R. Nelson (Eds.), The Oxford handbook of innovation (pp. 487-513). New York, NY: Oxford University Press.

Vivarelli, M. (2013). Is entrepreneurship necessarily good? Microeconomic evidence from developing and developed countries. Industrial and Corporate Change, 22(6), 1453-1495. 
Wade, R. (1990). Governing the market: Economic theory and the role of government in East Asian industrialization. Princeton NJ. Princeton University Press.

Wolf, C. (1988). Markets or governments: Choosing between imperfect alternatives. Cambridge, Mass.: MIT Press.

Wood, R. (2012). Fallen Solyndra won bankruptcy battle but faces tax war. Forbes, 11 June http://www.forbes.com/sites/robertwood/2012/11/06/fallen-solyndra-won-bankruptcy-battle-butfaces-tax-warl (accessed 29/6/2014).

Wright, B. D. (2012). Grand missions of agricultural innovation. Research Policy, 41(10), 17161728. 
Recent papers in the SPRU Working Paper Series:

SWPS 2015-16. Davide Consoli, Giovanni Marin, Alberto Marzucchi, Francesco Vona. May 2015. Do Green Jobs Differ from Non-Green Jobs in Terms of Skills and Human Capital?

SWPS 2015-17. Anders Bornhäl, Sven-Olov Daunfeldt, Niklas Rudholm. May 2015. Employment Protection Legislation and Firm Growth: Evidence from a Natural Experiment.

SWPS 2015-18. Phil Johnstone, Andy Stirling. June 2015. Comparing Nuclear Power Trajectories in Germany And the UK: From 'Regimes' to 'Democracies' in Sociotechnical Transitions and Discontinuities.

SWPS 2015-19. Maria Savona. July 2015. Global Structural Change And Value Chains In Services. A Reappraisal.

SWPS 2015-20. Javier Lopez Gonzalez, Valentina Meliciani, Maria Savona. July 2015. When Linder Meets Hirschman: Inter-Industry Linkages and Global Value Chains in Business Services.

SWPS 2015-21. J. Sylvan Katz. July 2015. What is a Complex Innovation System?

SWPS 2015-22. Friedemann Polzin, Paschen von Flotow, Laurens Klerkx. August 2015. Accelerating the Cleantech Revolution: Exploring the Financial Mobilisation Functions of Institutional Innovation Intermediaries.

SWPS 2015-23. Tommaso Ciarli, Alex Coad, Ismael Rafols. August 2015. Quantitative Analysis of Technology Futures: A review of Techniques, Uses and Characteristics.

SWPS 2015-24. Lee Stapleton. August 2015. Do Academics Doubt Their Own Research?

\section{Suggested citation:}

Mariana Mazzucato (2015). From Market Fixing to Market-Creating: A New Framework for Economic Policy. SPRU Working Paper Series (SWPS), 2015-25: 1-19. ISSN 2057-6668. Available at www.sussex.ac.uk/spru/swps2015-25

\section{SPRU - Science Policy Research Unit}

University of Sussex

Falmer, Brighton, BN1 9SL,United Kingdom

www.sussex.ac.uk/spru

Twitter:@SPRU

SWPS: $\underline{w w w . s u s s e x . a c . u k / s p r u / r e s e a r c h / s w p s}$ 